\title{
STATISTICAL MODELS OF REPRESENTING INTELLECTUAL CAPITAL
}

\author{
Andreea Feraru \\ "Vasile Alecsandri" University of Bacau \\ andreea_feraru26@yahool.com
}

\begin{abstract}
This article entitled Statistical Models of Representing Intellectual Capital approaches and analyses the concept of intellectual capital, as well as the main models which can support enterprisers/managers in evaluating and quantifying the advantages of intellectual capital. Most authors examine intellectual capital from a static perspective and focus on the development of its various evaluation models. In this chapter we surveyed the classical static models: Sveiby, Edvisson, Balanced Scorecard, as well as the canonical model of intellectual capital. Among the group of static models for evaluating organisational intellectual capital the canonical model stands out. This model enables the structuring of organisational intellectual capital in: human capital, structural capital and relational capital. Although the model is widely spread, it is a static one and can thus create a series of errors in the process of evaluation, because all the three entities mentioned above are not independent from the viewpoint of their contents, as any logic of structuring complex entities requires.
\end{abstract}

\section{Keywords}

organisational intellectual capital; human capital; structural capital and relational capital; internal structure and external structure

\section{JEL Classification}

F15; F50; O10

\section{Concepts and Models of intellectual capital}

Attention to the concept of intellectual capital (IC) has appeared with the notification of the significant differences between the market value of a company and the net book value.

It seems that this phrase is attributed to the American economist John Kenneth Galbraith, about 30 years ago. Galbraith suggests that this concept means more than knowledge or pure intellect, it means action.

Thus, intellectual capital is a way of creating value and a resource in the traditional sense (Roos et al., 1997). It is not enough to have an organization people with high intellectual capacity, if these resources are not adequately used in the creation of value.

Much of the increased interest in this area is probably due to Thomas Stewart, who first used the term of intellectual capital in the press (in the article "Article Brainpower", 1991, published in Fortune magazine). That year, Skandia him Leif Edvinsson appointed as the first director of intellectual capital in the world (director of intellectual capital), and only four years later Skandia already publishes his first public report on intellectual capital (Andriessen, 2004).

In classical economic theory, capital is one of the three factors of production, in addition to land, and labor. It refers in particularly to buildings, equipment, machinery etc., which are used to produce other goods (in literature it is also used the phrase 
physical capital). Thus, intellectual capital is a term that is used to signal the presence of otherwise capital, different physical and financial capital (Peltoniemi, 2006).

Brătianu (2006) considers that extending the semantics of a fundamental concept, such as the capital, may be more difficult than defining a new concept. Therefore, specialists in various fields (economic, management, accounting) tried to define more precisely the concept of intellectual capital. There are several approaches to this concept, showing on the one hand the difficulty of defining something as "untouchable" and, on the other hand, its importance in the society and economy of knowledge.

The conceptual framework of intellectual capital includes three directions, leading to a complex picture of the concept, and therefore to a better understanding of it.

A first direction comes from the field of accounting. The term most commonly used by the accounting community is that of intangible assets. Van den Berg (2003) believes that traditional financial accounting systems have lost the ability to provide information regarding the value of an organization, value that is being increasingly given by intangible assets. Lev (2002) estimated that $60-70 \%$ of the value of a company is given by intangible assets (van den Berg, 2003).

Moreover, investments in intangible assets considerably exceed those in tangible assets, further increasing the difficulty in estimating the fair value as a company. Leonard Nakamura has calculated that in 2000, private US companies have invested in intangible assets 1,000 billion, on par with gross private investment in tangible assets; In the same year, the stock of intangible assets in the US economy reached 5.000 billion, accounting for half the market value of all existing corporations (Dragomirescu, 2004).

However, even people who support the adequacy of traditional accounting systems are concerned about the possible introduction of elements that may be regarded as subjective - non-financial elements in annual reports. If it would be a mistake to combine financial indicators with non-financial indicators, a much bigger mistake would be to ignore the latter (Stewart, 1999).

In most accounting manuals and articles occur various situations (eg resignation of a manager) that, while recognized as important, are not shown in traditional financial accounting documents. Such situations can seriously affect a company but are overlooked in terms of accounting reporting.

Moreover, the accounting community faces in relating to intangible assets as they complicate things regarding an accounting fundamental concept, namely the independence of the exercise, which involves a strict delineation in time of the revenue and expenditure for the financial year for which the reporting is made, regardless of date of receipt or payment amounts, basic requirement of accrual (Andriessen, 2003).

A second way is to find a suitable matrix for the intellectual capital. In this regard we have been developed various models of assessment of the intellectual capital.

Many authors have tried to capture in a few words the essence of the concept of intellectual capital. According to Stewart (1999), intellectual capital is "intellectual material - knowledge, information, intellectual property, experience - that can be used to create wealth" (p. XI).

In the same direction also fit the definitions given by Hugh MacDonald "knowledge that exists in an organization and can be used to create competitive advantage" (Stewart, 1999, p. 67) and by Leif Edvinsson (Skandia) and Pat Sullivan "knowledge that can be converted to value" (Sveiby, 2001).

It is an intellectual potential, consisting of knowledge in various forms, that has the ability to transform itself into technological processes and management in a number 
of operational elements, assets, creating value, to be integrated into end products such materials and a company's intangible (Brătianu, 2006).

But these definitions are too vague to be helpful managers. David Klein and Laurence Prusak try to capture a more pragmatic intellectual capital. They consider intellectual capital as "intellectual material that has been formalized, captured and used to produce an asset of greater value" (Stewart, 1999, p. 67).

Therefore, an engineer with great intellectual potential, but who is isolated in an office, doing routine things, report lost on the head office, are intellectual material, but they are not and intellectual capital, as they were not used.

However, it is quite complicated to determine exactly which resources and how they contributed to an asset of greater value. For this reason, the operational performance of such an approach is also quite low.

From the definitions given so far by different authors can deduce some characteristics of intellectual capital:

1. It is intangible, although some elements may be associated intellectual capital and material form (ie patents, trademarks);

2. There is a close connection between intellectual capital and knowledge in various forms;

3. Provide opportunities to achieve higher performance in the future.

Due to the strategic importance of intellectual capital, the prevalence of establishment of responsibility for their management (eg Chief Knowledge Officer, Director of Intellectual Capital etc) and employment status with loads of conception (knowledge worker) has become a common presence in contemporary organizations, going beyond the borders of the research sector (Dragomirescu, 2004).

Moreover, the creation of such management functions as a totally new show in terms of intellectual capital, the business world is far ahead of theorists and researchers from academia (Brătianu, 2006).

As it can be seen from the above definitions, it is quite complicated for a definition of a few lines to capture the essence of the concept of intellectual capital and to provide a complete picture both conceptually and practically.

Therefore, both practitioners and researchers in the field IC prefer to use as a starting point in their approaches different classifications of intellectual capital components. For example are quite a few models measuring / evaluating the intellectual capital that do not use such a classification (This is especially models that have been developed specifically to assess intellectual capital. But with intensified concerns for IC field, they have been employed for this purpose).

The most commonly used classification is the one that divides intellectual capital into three components: human capital, relational capital (customers) and structural capital. Stewart (1999) attributes this taxonomy Leif Edvinsson of Skandia's and Hubert Saint Onge.

However, it should be noted that Leif Edvinsson, according to Market Value Scheme divides intellectual capital into human capital and structural capital, which in turn consists of the share customer and organizational capital, the latter being constituted in turn in innovational capital and capital processes.

Although it seems well structured, the classification uses groups of entities that are neither well defined, nor unique. For example, structural capital comprises organizational capital, although the structure is part of an organization and not vice versa (Brătianu, 2006).

Thus, increasingly more authors use them in their empirical classification of intellectual capital in human capital, structural capital (organizational) and relational capital (customers). 
A similar classification is Sveiby's model, which classifies intangible assets in the external structure, internal structure and individual skills. The external structure refers to customers, suppliers and other stakeholders that are considered relevant to a particular company.

Depending on the type of organization, the external structure will differ from one company to another. The internal structure refers to systems, databases, processes that support the organization. Individual competence refers to individual experience, knowledge, skills, abilities and ideas of employees.

By contrasting different models we see that there are different terms for the same item (ex: human capital skills $=$ internal, structural capital $=$ internal structure).

Bontis (2001) is unsatisfied with the situation illustrated above, considering that the main reason is the still embryonic phase of the field. Moreover, nobody wants to give up on their models and to build on already existing models and concepts (Andriessen, 2004). A brief overview of the existing classifications for intellectual capital is illustrated in Table 1

Table no 1. Components of intellectual capital

\begin{tabular}{|c|c|}
\hline Models & Components of intellectual capital \\
\hline $\begin{array}{l}\text { Indicator of market value - } \\
\text { net book value (Market-to- } \\
\text { Book Value) }\end{array}$ & $\begin{array}{l}\text { Intellectual capital is not presented components. According to } \\
\text { this model, intellectual capital is the difference between the } \\
\text { market value and net book value }\end{array}$ \\
\hline Indicator Tobin's Q Ratio) & Intellectual capital is not presented according to components. \\
\hline $\begin{array}{l}\text { Balanced Scorecard } \\
\text { (Norton şi Kaplan) }\end{array}$ & $\begin{array}{l}\text { Intellectual capital is not presented according to components. } \\
\text { This model suggests us to take a look at the organization from } \\
\text { four perspectives: learning and growth, internal process } \\
\text { perspective, customer perspective, financial perspective, which } \\
\text { largely resembles some of the components of intellectual capital } \\
\text { classifications developed later. }\end{array}$ \\
\hline $\begin{array}{l}\text { Sveiby Model } \\
\text { (Sveiby's Intangible Assets } \\
\text { Monitor) }\end{array}$ & $\begin{array}{l}\text { The external structure } \\
\text { Internal structure } \\
\text { Individual Skills }\end{array}$ \\
\hline Modelul Skandia & $\begin{array}{l}\text { Human capital } \\
\text { Capital structure, which in turn is divided into } \\
\text { customer capital and organizational capital, which is } \\
\text { innovational capital plus capital processes. }\end{array}$ \\
\hline $\begin{array}{l}\text { Roos et al Model } \\
\text { (Intellectual Capital Index) }\end{array}$ & $\begin{array}{l}\text { Human capital (skills, attitude, intellectual ability) } \\
\text { Capital structure (relational and organizational } \\
\text { innovation / development capital) }\end{array}$ \\
\hline $\begin{array}{l}\text { The Technology Broker' } \\
\text { IC Audit }\end{array}$ & $\begin{array}{l}\text { Active market } \\
\text { Human capital } \\
\text { Intellectual property } \\
\text { Capital infrastructural }\end{array}$ \\
\hline
\end{tabular}

IC community has evolved a lot in recent years and the focus shifted to evaluation / measurement IC, developing assessment statements IC, IC strategic management. However, as more rigorous definition of the basic concepts is necessary for empirical approaches of the researchers in the field, but it is also used to increase the capacity for the implementation of research results into practice.

In this regard, we agree with the vision of Bontis illustrated above. There are too many names for the same elements, and this does nothing to hinder further research. Some researchers were concerned, particularly, by the form, and less by the background aspects. 
The appearance of a considerable number of models to assess the intellectual capital stresses that experts have not yet reached a consensus, but that there is a model supported by most businesses, because there are some difficulties in applying them.

Static models of representation of intellectual capital are based upon the analysis of tacit knowledge and explicit knowledge because they underlie the intellectual capital (Brătianu, 2011c).

Regarding the static knowledge, the models are seen as stock, which by their nature are static. Moreover, we can say that these models do not show us how we can increase the amount of capital coverage, moreover they lack the ability to show us how we can turn some of it into action and value.

Although human capital is the most important component of intellectual capital, it can only be realized if there is a structural capital capable of transforming potential of human capital into capital.

Thinking patterns are virtual systems processing information and knowledge at the individual level. They are formed through education in the family, in school, in the community or by the individual himself. From the point of view of time, thought patterns can be static, dynamic and entropic (Bratiano and Murakawa, 2004 Brătianu, 2007).

In short if static models, knowledge (intangible resources) are based on the metaphor of "knowledge regarded as stocks and flows" in dynamic models, which are based on the metaphor of "field".

\section{References}

Andriessen, D. (2004), Making Sense of Intellectual Capital - Designing a Method for the Valuation of Intangibles, Amsterdam: Elsevier.

Bontis, N., (1998), Intellectual capital: an exploratory study that develops measures and model, Management decision.

Brătianu, C. (2006), Un model de analiză a capitalului intelectual organizațional, Management \& Marketing, vol. 1, nr. 3, pp. 17-33.

Brătianu, C. (2007), Thinking patterns and knowledge dynamics. Proceedings of the 8th European Conference on Knowledge Management, 6-7 september 2007, Barcelona, pp. 152-157, vol. 1, published by Academic Conferences Limited, Reading.Brătianu, C. (2008) A dynamic structure of the organizational intellectual capital, in: Naaranoja, M. (ed.) Knowledge management in organizations, pp. 233-243. Vaasa: Vaasan Yliopisto. Brătianu, C., (2009), Dinamica cunoştinţelor.

Brătianu, C. (2011 a), Changing paradigm for Knowledge metaphors from dynamics to thermodynamics, Systems Research and Behavioral Science, 28, pp. 160169.

Brătianu, C. (2011 b), A new perspective of the intellectual capital dynamics in organizations, in: Belen Vallejo-Alonso, Arturo Rodriguez-Castellanos, Gerardo Arregui-Ayastuy (eds.), Identifying, measuring, and vahing knowledge-based intangible assets: new perspectives, pp.1-21. New York: Business Science Reference.

Brătianu, C. (2011 c), Knowledge and Intellectual Capital. București : Editura Business Excellence.

Brătianu, C., Murakawa, H. (2004) Strategic thinking, Transactions of JWRI, vol. 33, no.1, pp. 79-89. 
Feraru, A. (2009), The concept of knowledge and knowledge management in the Romanian business field, Studies and Scientific Researches - Economic Edition, Issue 14.

Feraru, A., (2011), Intellectual capital and knowledges - premises of he organizational development Proceeding Progress, Innovation, Democracy Horizon 2025, Tg. Jiu, ISSN* ISSN 2247-465X ISSN-L 2247 - 465X , pp. 631-635.

Feraru, A., Ciucescu N. (2011), Knowledge and the intellectual capital in modern organizations, Annals of the Oradea University. Fascicle of Management and Technological Engineering, ISSN 1583-0691, ISBN 978-606-10-0128-6 pp. 5106-5111.

Roos, G., Roos, J. (1997), Measuring your Company's Intellectual Performance. Long Range Planning, Special Issue on Intellectual Capital, vol. 30, No.3. 